\title{
Stem Cells for Neuro-regeneration: State of the Art
}

\author{
Wagih A., Elhawary S., Ellessy R. M., Esam B., Tarek I., Aamer M. \\ Faculty of Medicine, Cairo University, Cairo, Egypt
}

Email address:

halagabr@yahoo.com

To cite this article:

Wagih A., Elhawary S., Ellessy R. M., Esam B., Tarek I., Aamer M.. Stem Cells for Neuro-regeneration: State of the Art. American Journal of Bioscience and Bioengineering. Special Issue: Stem Cells for Neuro-regeneration: Where Do We Stand. Vol. 3, No. 4-1, 2015, pp. 56-70. doi: $10.11648 /$ j.bio.s.2015030401.19

\begin{abstract}
Neuroregeneration (NR) is a long-sought medical dream which has intrigued vast research in the past decades. A traditional physiologic dogma that central nervous system does not regenerate has been strongly challenged in the recent years since the advent of the stem cell era. Stem cell research in the regenerative field passes through three main stages. The first stage is the in-vitro experiments which studies the exact molecular and cellular mechanisms underlying stem cell-mediated NR The second stage is the application of these data in experimental animal settings to provide "proof of concept" of stem cell therapy in animal models. The final step is the translation of these data in pilot clinical trials. In this review, we will try to gather the different data of stem cell-mediated NR from various experimental and clinical researches.
\end{abstract}

Keywords: Neuroregeneration, Stem Cells, Mesenchymal Stem Cells, Parkinsonism, Transdiffereniation

\section{Introduction}

(NR) is a broad term that comprises neurogenesis, neurorestoration and neuroplasticity as a therapeutic approaches. Neuroregeneration is a long-sought goal in medicine. The exploding knowledge in stem cell biology and its translational medicine is raising hopes for revolutionary changes in many concepts of NR. This review is intended to highlight the important steps taken until now in this field and give an idea about the state of the art in this hot area of scientific research.

The human central nervous system (CNS) is a complex organ which contains about 1011 (100 billion) neurons and 10-50 times this number of glial cells. It has been calculated that $40 \%$ of the human genes participate, at least to a degree, in its formation (1).

Nervous system injuries affect over 90,000 people every year. It is estimated that spinal cord injuries alone affect 10,000 each year. Peripheral nerve injuries constitute the rest of this figure. According to the World Health Organization, one out of 6 of the world's population suffer from neurological damage (2).

In order to elicit meaningful regeneration, neurons must go through both anatomical and functional regeneration. Mechanisms of normal regeneration differ dramatically between central and peripheral nerves.

\section{Regeneration in the CNS}

\subsection{Anatomical or Axonal Regeneration in CNS}

Axon re-growth in the CNS takes one of two forms: either actual regenerative growth from the injured axon, or compensatory sprouting from neighbouring spared axons.

Unlike peripheral nervous system injury, injury to the central nervous system is not followed by proper regeneration. It is limited by the inhibitory influences of the glial and extracellular environment. The hostile, nonpermissible growth environment is, in part, created by the migration of myelin-associated inhibitors, astrocytes, oligodendrocytes, oligodendrocyte precursors, and microglia. The environment within the CNS, especially following trauma, counteracts the repair of myelin and neurons.

Axon regeneration in the CNS fails for two reasons:

1) The hostile microenvironment surrounding CNS lesions which is inhibitory to axon growth,

2) Most CNS axons fail to exhibit an effective regeneration response after they are cut.

\subsection{Factors Affecting CNS Regeneration}

\subsubsection{Intrinsic Factors}

A number of cellular and molecular pathways in the CNS neurons contribute to the defective regeneration. These 
factors either prevent axon regeneration, inhibit neuronal growth, act as generalized growth inhibitory molecules, or act through inhibition of myelination. They may be classified into the following groups:

Axon Guidance Molecules:

Tenascins

Tenascins are a family of extracellular matrix glycoproteins which displays highly dynamic patterns of expression during development and after nervous system injury. Tenascins are inhibitory molecules preventing axon regeneration into the dorsal root entry zone (DREZ) (3).

Semaphorins:

Semaphorins are inhibitory or repulsive guidance cues whose function is network stabilization by inhibiting neuronal growth. During injury, semaphorins, especially semaphorin3A are expressed by glial scar associated meningeal cells and are responsible for growth inhibition. Injury to the dorsal columns of the spinal cord induced strong expression of semaphorin3 A mRNA in fibroblasts associated with the glial scar, and semaphorin $3 \mathrm{~A}$ receptors were present on injured dorsal column axons; dorsal column axons fail to penetrate the semaphorin3Aexpressing scar tissue (4).

Ephrins:

Similar to the semaphorins, the predominant neuronal response to ephrins is repulsive. Ephrins bind to members of the EphA and EphB receptor tyrosine kinase families. Of interest for nervous system regeneration is the strong expression of ephrinB3 in CNS myelin, the injury-induced up-regulation of ephrinB2 in reactive astrocytes, and the increase in ephrinA5 expression around ischemic cortical lesions). In vitro, ephrinB3 is a strong inhibitor of neurite outgrowth for postnatal cortical neurons and functions in a EphA4-dependent manner (5).

WNTS:

The Wnt family mediate growth of anterior postcrossing commissural axons and posterior descending corticospinal axons $(6,7)$. The differential response of ascending and descending axons to Wnt stimulation is mediated by differential receptor expression Frizzled receptors mediate Wnt-4 attraction while atypical receptor tyrosine kinase Ryk promote Wnt-5a-mediated posterior growth of the corticospinal tract through repulsion $(6,7,8)$.

Myelin Inhibitors:

Prototypic Myelin Inhibitors: NOGO, MAG and OMgp:

Growth inhibitory molecules, not belonging to any of the known axon guidance molecule families, have been identified. These include the myelin-associated inhibitors Nogo-A, MAG, and OMgp, also known as the prototypic myelin inhibitors. Nogo-A (RTN4a) is a member of the reticulon (RTN) family of membrane associated proteins. It is comprised of two growth inhibitory domains: 1) AminoNogo, whose activity inhibits both neurite outgrowth and cellular adhesion of nonneuronal cell types, and 2) Nogo66, a 66-amino acid residue hydrophilic loop. Blocking of Nogo-A in rats has been reported to facilitate long-distance regeneration and sprouting of corticospinal axons; as well as growth of serotonergic fibers. Nogo neutralizing antibody infusions are now undergoing translational human testing in acute SCI (9).

Chondroitin Sulphate Proteoglycans (CSPGs):

Proteoglycans form the major inhibitory component in the glial scar. This is mediated through inhibiting axon regeneration and conduction of action potentials in undamaged nerve fibers close to spinal cord injuries. Proteoglycans consist of a protein core with attached highly charged sulfated glycosaminoglycan (sugar) chains. Digestion of the sugar chains with chondroitinase removes most of the inhibitory activity of the proteoglycans, thus promoting axon regeneration (10).

\subsubsection{Exogenous Factors}

To counteract the inherent cascades of regeneration inhibition in the CNS, several mechanisms can be addressed:

\subsubsection{Neurotrophic Factors}

During development, neurotrophic factors (NTFs) play a crucial role in axonal growth and pathfinding and neural circuit formation. These pivotal functions made these molecules excellent candidates for growth-promoting therapies. There are two families of neurotrophic factors: Neurotrophin family and glial cell line-derived neurotrophic factor (GDNF) families.

The neutrophin family consists of nerve growth factor (NGF), brain-derived neurotrophic factor (BDNF), neurotrophin 3 (NT-3) and neurotrophin 4 (NT-4). All neurotrophins bind to low affinity receptor $\mathrm{p} 75$, but their specific functions are mediated by distinct high affinity receptors: trkA for $\mathrm{NGF}$, trkB for $\mathrm{BDNF} / \mathrm{NT}-4$ and $\operatorname{trkC}$ for NT-3(11).

\subsubsection{Grafts and Transplants}

After spinal cord injury, peripheral nerve grafts provide neurotrophic support and growth substrate that permit CNS axons to regenerate. Olfactory ensheathing cells (OECs) myelinate olfactory axons and support growth of these axons from PNS to CNS throughout life .Transplanted OECs have been reported to promote axon regeneration, remyelination and functional recovery after spinal cord injury (12).

Embryonic spinal cord transplants have also been used to help injured dorsal root axons to regrow and reconnect with the denervated CNS. For example, after dorsal root injury, embryonic day 14 or 15 rat spinal cord transplants were grafted into the dorsolateral quadrant of adult rat spinal cord (13). 


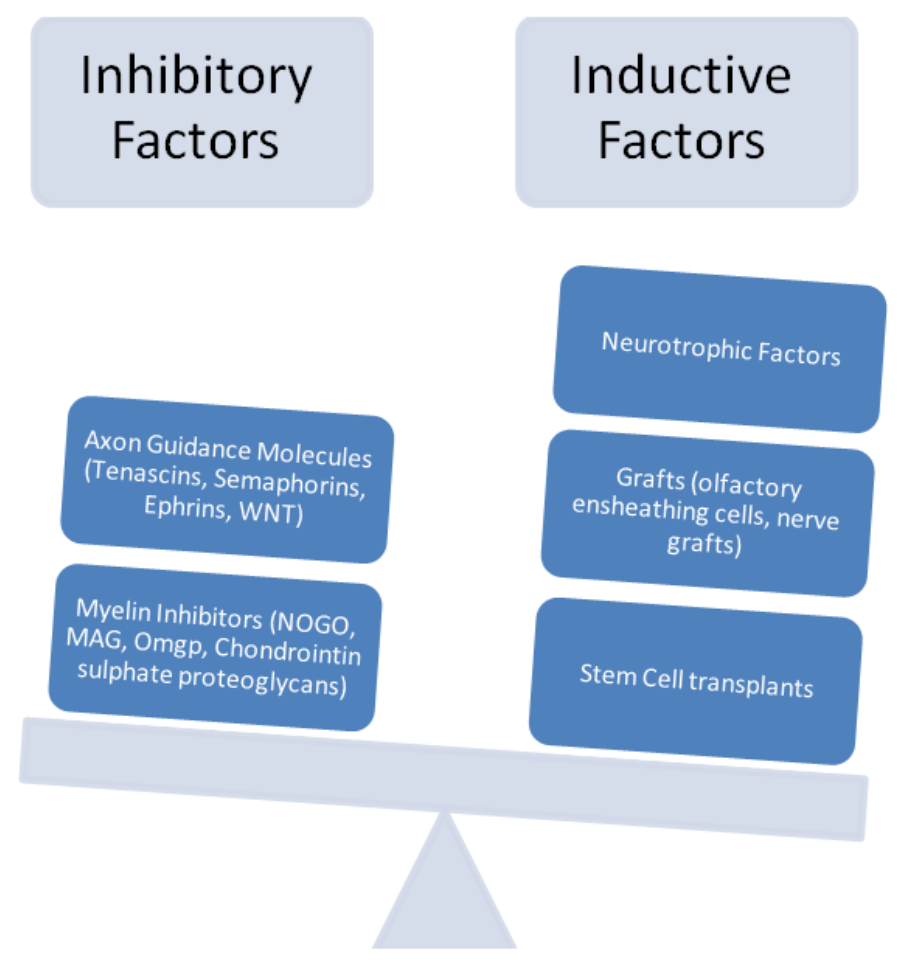

Figure (1). Factors affecting Neuroregeneration.

\subsection{Functional Recovery}

Functional recovery after nerve injury involves a complex series of steps, each of which may delay or impair the regenerative process. In cases involving any degree of nerve injury, it is useful initially to categorize these regenerative steps anatomically on a gross level. The sequence of regeneration may be divided into anatomical zones: 1) the neuronal cell body; 2) the segment between the cell body and the injury site; 3) the injury site itself; 4) the distal segment between the injury site and the end organ; and 5) the end organ itself. A delay in regeneration or unsuccessful regeneration may be attributed to pathological changes that impede normal reparative processes at one or more of these zones (14).

Functional motor recovery is impaired when significant numbers of axons do not successfully reform functional connections with the muscle. If the number of axons is adequate, errors in cross-innervation may result in defective functional result (15).

For optimum functional recovery, both motor and sensory recovery are mandatory. Functional outcome is sometimes impaired by mere sensory deficits, particularly in proprioception. Denervated sensory receptors survive and are amenable to functional recoveries after 1 year. In first- and second-degree injuries, sensory recovery is complete, even after 6 to 12 months of denervation (16).

After severe injuries and nerve repair, sensory recovery is never complete. This may be related to a combination of factors: failure of sensory axons to reach the skin, degeneration of sensory receptors and the possibility of cross-reinnervation $(15,16)$.

\subsection{Peripheral Nervous System}

Peripheral nervous system (PNS) neuroregeneration occurs to a more significant degree than in the CNS. Axonal sprouts form at the proximal stump and grow until they enter the distal stump.Injury to the peripheral nervous system immediately elicits the migration of phagocytes, Schwann cells, and macrophages to the lesion site in order to clear away debris such as damaged tissue.

Human axon growth rates can reach $2 \mathrm{~mm}$ /day in small nerves and $5 \mathrm{~mm} /$ day in large nerves. The distal segment, however, experiences Wallerian degeneration within hours of the injury; the axons and myelin degenerate, but the endoneurium remains. In the later stages of regeneration, the remaining endoneurial tube directs axon growth back to the correct targets. During Wallerian degeneration, Schwann cells grow in ordered columns along the endoneurial tube. This creates a band of Büngner (boB) that protects and preserves the endoneurial channel. Also, macrophages and Schwann cells release neurotrophic factors that enhance regrowth (10).

\subsection{Stem Cells}

Stem cells are immature cells that, in addition to the ability to proliferate, differentiate and home to tissue of origin, possess two unique properties: self-renewal and plasticity. Self-renewal is responsible for their ability for long-term repopulation of their respective tissues; while plasticity is the ability to change their fate between different lineages.

Stem cells are a large entity comprising a vast number of types that can be sorted according to their source, potency, 
and differentiation potential.

Stem cells carry a great hope for treating different neurological diseases, owing to its ability to maintain selfrenewal and differentiate to various cell types. This ability to mature and differentiate to different phenotypes involves complex events which can be affected by different regulatory molecules (20). Non-neuroectodermal stem cells as BM, blood, fat or dental pulp can induce neurogenesis when grafted along with neural stem cells. The neuro-regenerative effect of stem cells can be through a number of mechanisms. Stem cells can act through inducing endogenous neurogenesis and angiogenesis through its tropic effects (21). Mesenchymal stem cells (MSCs) in addition to its differentiation capacity can secrete neuroregulatory agents that help in neurogenesis, angiogenesis, immunomodulation, inhibition of apoptosis and glial scar formation, neural as well as glial cell survival and finally neuroprotective actions on different levels. This effect can be triggered by secretomes which also improve integration of local progenitor cells in neuroregeneration process opening the door for its future therapeutic application (22).

Stem cells can induce NR through a number of mechanisms: actual transdifferentiation into neural lineage, induction of angiogenesis, growth factor secretion or activation of endogenous stem cells (23). However, many degenerative disorders display preserved number of endogenous stem cells, with defective function or response to stimulatory signaling, The role of SC therapy is to change the milieu of degenerated stem cells with introduction of normal cells to function as stem cell niche, immunomodulatory cells and growth factor secreting cells (24).

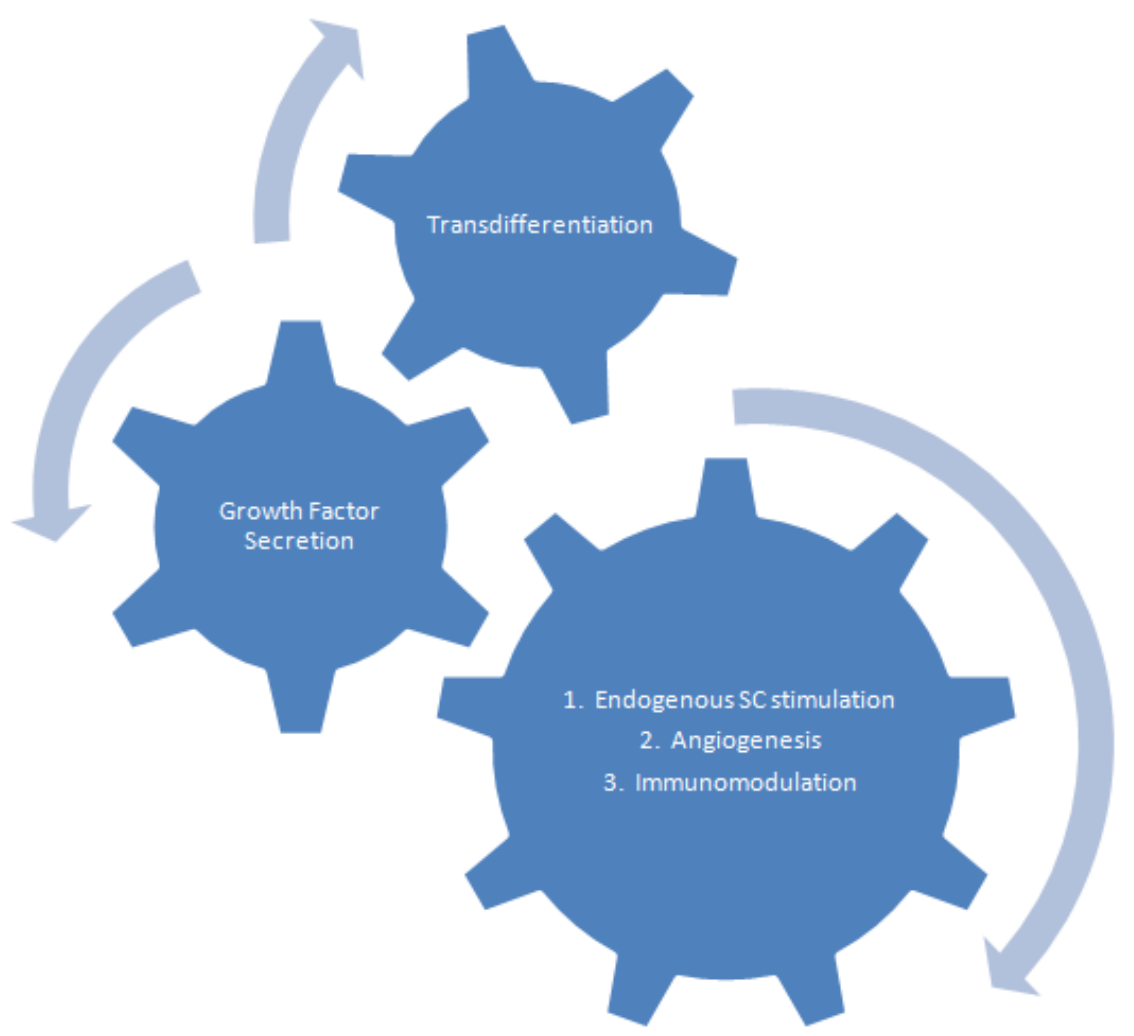

Figure (2). Mechanisms of Stem cell-induced Neuroregeneration.

\subsection{Mechanism of Stem Cell-induced NR}

Nearly all types of stem cells can be used for NR. The following are the types of SCs most reviewed in this context:

1. Embryonic SCs (ESC): Embryonic stem cells are grown from cells found in the at the blastocyst stage. ESCs exhibit totipotent ability, i.e., ability to differentiate into all body cells and fetal membranes. ESCs have successfully induced to express neural lineage markers (25).

2. Adult SCs: The adult human body comprises a number of stem cell types of variable sources and potency. In terms of abundance, bone marrow derived stem cells ,whether hemopoeitic stem cells (HSC) or mesenchymal (MSC) are the best, followed by adipose derived stem cells (ADSC).

\subsubsection{Bone Marrow-derived Stem Cells}

1. HSC: These are multipotent stem cells which are the precursor of blood cells, they are harvested either from bone marrow "by bone marrow aspiration" or from peripheral blood following stem cell mobilization therapy.

2. MSCs: This is a type of multipotent stem cells that can be derived from different and have the ability to give rise to different type of cells "Mesenchymal and non-mesenchymal" The potential of differentiation depends on the type of origin (26).

\subsubsection{Adipose Derived Stem Cells (ADSC)}

ADSCs are multipotent cells derived from the stromal 
vascular fraction (SVF) portion of the processed lipoaspirate. Since first described by Zuk and colleagues in 2001, vast research has documented both the multipotency and plasticity of ADSCs.

\subsubsection{Neural SCs}

They are multi-potent stem cell capable of regenerating multiple neural cell lines as oligodendrocytes, neurons, and astrocytes. [27,28] Neural stem cells can be obtained from different sources such as adult and fetal nervous system, bone marrow, skin, adipose derived mesenchymal stem cells, and iPScs

\subsection{Induced Pluripotent SCs (iPS)}

IPS are differentiated cells treated to express pluripotency characteristics through the transfer of 4 pluripotency genes (OCT4, c-MYC, NANOG and SOX).

Table (1). Comparison between Biologic and Functional Characteristics of Different Stem Cell Types.

\begin{tabular}{|c|c|c|c|c|c|c|}
\hline \multirow{3}{*}{ Biologic Characteristics } & \multirow{3}{*}{$\begin{array}{l}\text { Embryonic Stem } \\
\text { Cell }\end{array}$} & \multicolumn{4}{|c|}{ Adult Stem Cells } & \multirow{3}{*}{ IPS } \\
\hline & & \multicolumn{2}{|c|}{ Bone marrow } & \multirow{2}{*}{$\begin{array}{l}\text { Adipose } \\
\text { (ADSC) }\end{array}$} & \multirow{2}{*}{ Neural SC } & \\
\hline & & MSC & HSC & & & \\
\hline 1. Potency & $\begin{array}{l}\text { Pleuri- } \\
\text { potent }\end{array}$ & $\begin{array}{l}\text { Multi- } \\
\text { potent }\end{array}$ & $\begin{array}{l}\text { Multi- } \\
\text { potent }\end{array}$ & $\begin{array}{l}\text { Multi- } \\
\text { potent }\end{array}$ & $\begin{array}{l}\text { Oligo- } \\
\text { potent }\end{array}$ & $\begin{array}{l}\text { Pleuri- } \\
\text { potent }\end{array}$ \\
\hline 2 Neuronal differentiation: & +++ & ++ & ++ & ++ & +++ & +++ \\
\hline 3. Functional neurones & \pm & ++ & ++ & ++ & +++ & \pm \\
\hline 5. Immunomodulatory & \pm & +++ & \pm & +++ & \pm & \pm \\
\hline 6. Angiogenesis & \pm & +++ & + & +++ & - & \pm \\
\hline 7. Teratoma formation & +++ & - & - & - & - & +++ \\
\hline 8. Rejection & +++ & - & +++ & - & +++ & +++ \\
\hline
\end{tabular}

\subsection{In-vitro Neuroregenerative Ability of Stem Cells}

\subsubsection{Role of In-vitro Studies in Neuroregeneration}

In-vitro experiments involving stem cell biology have the following functions:

1. Evaluation of the ability of each stem cell type to induce NR through testing neural transdifferentiation ability, neural growth factor production and immunomodulatory function. Comparison of the different stem cell types in each of these functions can be done.

2. Exploring molecular and cellular mechanisms of induction of NR

3. Evaluation of targeted therapy in NR

4. Exploring different methods of induction of neural transdifferentiation and evaluation of combined or stepwise induction of neural transdifferentiation.

\subsubsection{In-vitro Trials Involving Mechanisms of Stem Cell- Mediated NR}

In-vitro trials for chronic neurological disorders:

Parkinsonism

Parkinsonian disease (PD) is a neurodegenerative (ND) disease characterized by progressive dopaminergic neurons loss in substantia nigra pars compatica (SN) which may involve oxidative stress and high iron levels(30). In-vitro trials of stem cell modulation of PD reflects targeting all diseases processes.

Antioxidants either have been tested both invitro and invivo, natural as polyphenols as well as endogenous antioxidants as Vitamin A,C,E and Co-enzyme Q have shown protective effects against oxidative-induced neural death, mechanisms of so included: scavenging nitrogen and oxygen reactive species, regulation of cell-signaling pathways associated with cell survival and inflammation and finally inhibition of alpha-synuclein and synphilin-1.(31)
Recent studies found that alpha-synuclein may drive microglia to acquire maladaptive function and secrete neurotoxic molecules. In-vitro studies aim to modify disease process through acting on peroxisome-proliferator-activatedreceptor gamma (PPAR-gamma) agonists as pioglitazone and rosiglitazone which proved to be neuroprotective in this concern.(32)

Immunomodulatory agents such as Omega-3-fatty acids (omega-3-FA) as docosahexaenoic acid and eicosapentaenoic acid have an anti-inflammatory effect on microglia invitro.(33)

In-vitro studies have shown that mGlu3 receptors in basal ganglia (BG) have shown that it can inhibit transmission across overactive synapses and hence symptoms relief. In addition, it has a neuroprotective role in preventing progressive degeneration as well as its role in releasing neurotropic factors.(34)

In-vitro experiments have proven the ability of transdifferentiation of various stem cell types into dopaminergic neurones, thus providing more evidence for stem cell therapy in PD (35).

Huntington Disease (HD)

$\mathrm{HD}$ is a ND disease characterized by polyglutamine expansion in Huntington protein, alteration in kynureine pathway (KP) metabolism with consecutive changes in KP metabolites is the hallmark of the disease. The 3 metabolites $\mathrm{KP}$ are: the neurotoxins 3-hydroxykynurenine (3-HK) and quinolinic acid (QUIN), and the neuroprotectant kynurenic acid (KYNA). In invitro and invivo models it was found that 3-HK and QUIn are associated with neurodegeneration while KNYA is not. The enzyme kynurenine 3-monooxygenase (KMO) is located at a critical branching point in the KP such that the inhibition of this enzyme by any mean will shift the flux towards KNYA formation thus ameliorating the disease. 
Thus, KMO has been marked as the future therapeutic target for this disease.(36) Altered iron homeostasis also has been described in Huntington disease (HD), invitro studies results supported this data.(37)

Amylotropic lateral sclerosis (ALS)

ALS IS a devastating neurological disorder which has a vascular component. Invitro studies proved that molecules like vascular endothelial growth factor (VEGF) have a therapeutic, diagnostic and prognostic potential in ALS. Its deletion along with superoxide dismutase (antioxidant) can result in ALS like phenotype, thus proposing a vascular therapeutic and diagnostic modality.

In-vitro studies have proven the directed conversion of mesenchymal stem cells into functional motor neuron-like cells as a step towards transplantation in motor neuron disease(38)

Alzheimer disease (AD)

Alzheimer disease (AD) is due to deposition of amyloid fibrils that consists of Amyloid beta (Abeta) proteins, therefore inhibition of Abeta formation by transthyretin, a natural neuroprotector protein in CSF, or Abeta-transthyretin complexes mimetic should inhibit amyloid formation as proved invitro.(39)

A neural compound come from algae called homotaurine (tramiprosate)has been tested invitro and now in phase 3 clinical study to be beneficial preventing $\mathrm{AD}$ owing to its anti-amyloid activity and gamma-amino butyric acid type A receptor affinity.(40)

Calcium channel blockers (CCBs) showed invitro to attenuate amyloid-B induced neural decline, high intracellular calcium load in the pathophysiology of $\mathrm{AD}$ is thought to be brought by the high amyloid-B deposits extracellular. It has shown later in preliminary clinical trials that the vasodilatation in cerebral vasculature caused by CCBs help lessening dementia which is caused mainly by hypo-perfusion. (41)

Phospholipase (PLA2s) has emerged as having a neuroregulatory role since 15 years, owing to its effect on inflammation and lipid metabolism, which may be affected either by CCBs. Through a well-constructed review on different PLA2s as contributing to the pathogenesis of $A D$, it was found that SPLA2-2a and sPLA2-5 as well as cPLA2-4a are involved in neuronal death and degeneration while cPLA2 and iPLA2 are involved in neurogenesis and thus should not be inhibited.(42).

Stem cells differentiate into neurons capable of replacing damaged cells in $\mathrm{AD}$ functionally, thus reversing its symptoms(43).

Blindness

Pituitary adenylate cyclase activating peptide (PACAP) is a neurotrophic factor that has been proved to have protective effects against various neuronal injuries, PACAP and its receptors are present in retina. PACAP testing invitro has shown protection against glutamate, anisomycin, anoxia and thapsigargin giving a new treatment modality for retinopathy patients.(44)

The recent success in culturing a whole optic disc in-vitro which has a large number of photoreceptors might be generated from embryonic stem cells without the need for embryo donor; this can be transplanted to restore the photosensitive component and hence vision in blind patients.(45)

In-vitro trials for general neurological disorders

Blood brain barrier (BBB) is a major determinant in neuroregeneration. After inflammation, BBB shows increased permeability allowing inflammatory cell leakage, thus exaggerating injury. This is mediated through inflammatory mediators and complement activation products. Inhibition of $\mathrm{C} 5 \mathrm{aR} 1$ signaling in endothelial cells in-vitro appeared to be protective, which may make it future therapeutic target.(46)

\subsection{Stem Cell Therapy in Animal Preclinical Trials: Where We Stand}

Preclinical animal models are vital in development of new therapeutic approaches. They provided "proof-of-concept" of the effect of cellular therapy in specific disease conditions. They provide objective evidence regarding stem cell homing, transdifferentiation and mode of regenerative action. They also provide an excellent experimental setting to compare different routes of injection cell dose and mode of evaluation.

In this section we will try to highlight the most important experimental animal studies involving the use of stem cells for induction of NR.

Neurodegenerative diseases:

Amyotrophic lateral sclerosis (ALS)

About $10 \%$ of ALS cases are familial (fALS), among which $15-20 \%$ is due to mutations in $\mathrm{Cu} / \mathrm{Zn}$ superoxide dismutase (SOD1) [49]. Stem cells used in ALS may be directed towards regenerating damaged neurones or introduction of cells producing growth factors. Enhancement of protective GF productions hinder \& slow the progress of the disease, this approach exploits the regenerative ability of stem cells to express growth factors, so as to decrease the burden on the endogenous system [72]. Such a combination of treatment with stem cells and growth factor may provide massive neuroprotection in ALS [47].

The most prominent trials in this field are:

1. Embryonic Stem Cells:

By using embryonic stem cells (ES cells) from mice carrying transgenic alleles of SOD1 gene to generate motor neurons in vitro [50], in 2011 Wyatt $\mathrm{TJ}$ et al, transplanted these ES cells into SOD1G93A rodent model of ALS results in enhancing the numbers of endogenous neurons [51].

Intra-spinal transplantation of ESC-derived motor neurons into SOD1G93A rats showed functional improvements, but no long-term effects on the lifespan of the rats, and limited graft survival [64

2. Mesenchymal Stem Cells:

In 2012 Lee JC et al. used bone marrow cells (BMCs) in SOD1G93A transgenic mice and the results show improvement of the neural cell microenvironment \& slowing disease progression [54]. But human clinical trials as observed by Gamez $\mathrm{J}$ et al. showed that cell transplantation 
in human clinical trials don't affect the course of the disease [55]. Usage of MSCs and BMCs as Trojan horses to deliver trophic factors is another step for palliative or curative treatment in ALS. [48, 56, 57, 58]. In 2008 ,Suzuki et al. reported that delivering glial cell line-derived neurotrophic factor (GDNF) by using human mesenchymal stem cells (hMSCs) in rat model of fALS abolished neuromuscular junction denervation thus increase survival $\&$ improve motor function [52].

3. Hemopoeitic Stem Cells:

In 2010 Corti $\mathrm{S}$ et al. use specific bone marrow derived ckit(+) stem/progenitor cells from wild-type mice \& transplanted them in SOD1G93A mouse resulted in delayed progression, prolonged survival \& improving neuromuscular function in ALS models[53].

4. Adipose Derived Stem Cells:

Although preclinical trial using SCT in ALS mainly directed to the usage of MSCs \& BMCs [3], but there are also few preclinical trials using Adipose derived stem cells (ADSCs) was done and show increase levels of growth factors like basic fibroblast growth factor (bFGF), Insulinlike growth factor 1 (IGF-1), Vascular endothelial growth factor (VEGF), Nerve growth factor (NGF) and also increase levels of neurotrophic factors as glial-derived neurotrophic factor (GDNF), Brain-derived neurotrophic factor (BDNF) this show neuroprotective effects and prolongs the life span of ALS mice [60, 61].

5. Neural Progenitor Cells:

Transplantation of Progenitor cells as Neural progenitor cells (NPCs) has the ability to provide neurotrophic support, improve endogenous neuroregenerative mechanisms, and maintain neurocircuitry and provide positive effects on the ALS course [63, 64]. Also transplantation of glial-restricted progenitor cells \& olfactory ensheathing stem cells (OESCs) shows positive effects in the survival of the ALS disease [65, 66].

Loss of neurotrophic factors \& growth factors (including GDNF, BDNF, VEGF, and IGF-1) has been implicated in the pathogenesis of ALS [67]. These factors play a neuroprotective role for motor neurons also physical exercise appeared to be beneficial in animal experiments [68-71].

The main problem in the future of preclinical trials is that strategies of therapy emerged in animal trials show less efficacy in the human clinical trials. Also preclinical trials rarely reproduce identical models to form the clinical translation $[73,74]$.

Also transition from preclinical to clinical human trials may result in hazardous, sometimes reversed outcome, for example using minocycline in treatment of ALS show slowing progression of the disease in mutant SOD1 transgenic mice but transition this results into human trials minocycline accelerate the course of ALS[75].

\subsection{Alzheimer's Disease (AD)}

1. Neuronal Stem Cells:

The ability of neuronal stem cells (NSCs) to differentiate into multiple cell lineages make it suitable for transplantation in animal models of $\mathrm{AD}$, either to acquire its ability for differentiation or use it as a vehicle for delivery Growth factors [76].

Lee HJ et al. \& Yamasaki TR et al. showed that transplantation of NSCs differentiate into mature cells in the animal models of $\mathrm{AD}$ and improve learning \& memory [77, 78]. Also Xuan AG et al. showed that transplantation of rat NSCs leads to increase numbers of cholinergic neurons and thus improve memory $[79,80]$.

This procedure also increase neutrotrophic factor levels and lead to behavioral improvement without changing the pathogenesis of $\mathrm{AD}$, among these neurotrophic factors: brain-derived neurotrophic factor (BDNF) which is critically important in hippocampus \& entorhinal cortex and nerve growth factor $(N G F)$ which affect the function of cholinergic neurons in forebrain [81]. Also NSCs transplantation was found to elevate glial-derived neurotrophic factor (GDNF) in transgenic models of AD [82].

However, NSCs itself did not affect significantly the $A \beta$ plaques of mice models But it was found to be helpful is replacing the cells and thus improve the course of AD [83].

Delivery of neurotrophic factors using NSCs transplantation as neprilysin, plasmin, insulin degrading enzyme and cathepsin B, is shown to be a very effective strategy in approach to $\mathrm{AD}$ [76] as these factors helps to decrease amyloid-beta $(\mathrm{A} \beta)$ protein level in mice models [84.

Using Adipose derived Stem cells (ADSCs) is promising source for neuroregeneration in $\mathrm{AD}$ model, Intracerebral administration of ADSCs showed increase in level of $A \beta$ protein level thus leads to restore spatial cognitive abilities in APP/PS1 double transgenic mice [85], in another type of AD model, IV administration of ADSCs decrease dementia symptoms $[86,87]$.

2. Adipose Derived Stem Cells:

Also administration of human ADSCs was found to be beneficial in improvement of $\mathrm{AD}$ in animal models, as it was found to secrete neprilysin which is the most important enzyme in degradation of $\mathrm{A} \beta$ protein level in brain tissue [88].

3. Neural Progenitor cells (GABAergic interneuron precursor cells):

GABAergic interneuron precursor cells which are produced from medial ganglionic eminence (MGE) which is transient embryonic structure developed in the brain [89], transplantation of these precursor cells in hippocampus of mice 88,57 showed development into mature functioning cells which integrated into the hippocampus \& improve learning \& memory $[90,91]$. This shows that MGE have the characteristics for stem cell therapy including high ability for migration differentiation \& circuit modulation [92]. In 2013, Liu $Y$ et al. derived human cortical interneurons which mature to form GABAergic interneurons then transplanted into mice model of AD and showed improvement in learning $\&$ memory [93].

4. Mesenchymal Stem Cells:

Chronic inflammation has an important rule for the pathogenesis of AD [94], transplantation of Mesenchymal stem cells (MSCs) elevates the level of many anti- 
inflammatory Cytokines including IL-10 \& PGE2 thus improve cognitive functions in transgenic AD mice [95]. Cord-blood derived MSCs showed to stimulate production of neprilysin in microglial tissue [96]. Even human cord blood shown to modulate signaling of CD40 thus reduces $\mathrm{AD}$ pathology [97]. Bone marrow derived MSCs (BM-MSCs) were showed to remove amyloid-beta $(\mathrm{A} \beta)$ protein level from hippocampus of AD mice model [98].

Due to multiple hypotheses in pathogenesis of $\mathrm{AD} \&$ multiple phenotypic neurotransmitters, researches on use SCT has lagged behind other neurodegenerative disorders like Parkinson's disease, making using of stem cell transplantation is very challenging [99].

A major challenge in $\mathrm{AD}$ is the establishment of animal model allowing human xenotransplantation of NSCs without the need to use immunosuppressant which was found to alter the pathology of $\mathrm{AD}[99,100$

\subsection{Huntington's Disease}

There are two broad types of Huntington's disease (HD) modeling: genetically modified \& excitotoxic lesion models [101]. Ecitotoxic lesion models are done by either intrastrial administration of glutamic acid and quinolinic acid (QA) which leads to striatal atrophy \& degradation of GABAergic medium spiny projection neurons [102] or administration of 3-nitropropionic acid (3-NP) which leads to irreversible inhibition of succinate dehydrogenase leading to permanent strial death [103, 104].

1. Neural Stem Cells:

Neural Stem Cells (NSCS) has been used as a possible option for stem cell based therapy, studies using NSCs have been done to measure the effect and route of their transplantation in both models of HD either QA or 3-NP models[ 101]. In 2004 Ryu et al. transplanted human NSCs (hNSCs) into rat models of HD before \& after treatment with 3-NP and showed improvement in motor functions, decreased cellular damage, differentiation of hNSCs into GABAergic neurons and increased level of BDNF secretion [105]. McBride et al. transplanted hNSCs in QA models of HD and showed improvement in motor functions and reduced striatal atrophy [106]. Route of administration of NSCs is crucial. Lee ST et al. found that IV administration of hNSCs migrate to the lesioned striatum as intraventricular injection (which need invasive surgical technique) thus provide us less invasive route for administration of stem cells [107], so IV administration is shown to be more attractive if it is found effective in humans [108].

This migration may be due to specific conditions of the animal model such as QA effect which cause acute inflammation in the loci serve and produce cytokines which attract NSCs into the damaged area, So further studies must be carried to ensure the migration of NSCs if systemically injected [109].

2. Neural Progenitor Cells (NPCs):

Neural progenitor cells (NPCs) which were derived from subventricular zone (SVZ) of adult rats transplanted into a rat QA model of HD the results revealed increased motor functions, but NPCs which are derived from embryonic stem cells (ESCs) found to be superior in survival \& differentiation than NPCs rom SVZ [110].

3. Adipose Derived Stem Cells:

There are multiple studies use adipose derived stem cells $(A D S c)$ in animal models of $\mathrm{HD}$, direct transplantation of ADSc in YAC128 transgenic mice have showed secretion of growth factors which prevent apoptosis \& improve behavior in the mice [110]. In another studies, instead of direct transplantation of ADSc, Maucksch, $\mathrm{C}$ et al. intraperitoneal injection in R6/2 animals also showed improvement in behavior \& striatal atrophy [111]. Recent study showed that transplantation of ADSc not only decrease apoptosis but also reduce mitochondrial membrane potential \& reduce mitochondrial oxidative stress induced by HD, these results provide new approaches for understanding molecular mechanisms for ADSc in HD therapy [112].

4. Mesenchymal Stem Cells:

Bone marrow derived stem cells (BMCs) \& mesenchymal stem cells (MSCs) used in many studies mainly to induce neurotrophic factors (NTFs) like Brain-derived neurotrophic factor (BDNF), nerve growth factor (NGF), glial cell linederived neurotrophic factor (GDNF) and ciliary neurotrophic factor (CNTF). These factors were found to have beneficial effect on the course of HD [113, 114].

Another approach in using MSCs transplantation to improve survival directly, by using them in different models of HD mice it showed improvement in working memory, reduced striatal atrophy $[115,116]$.

MSCs have another advantage as it form a weak immune response \& its combination with NSCs increase the survival of NSCs rather than transplantation of NSCs alone. This makes the MSCs transplantation is an effective \& less hazardous approach in HD therapy $[117,118]$.

\subsection{Parkinson's Disease}

Parkinson disease (PD) is considered as the railcar of the train of stem cell research, due to the relatively fixed pathology of the PD \& the prominent relation between clinical picture and loss of dopaminergic neurons, it is always the ideal candidate for stem cell therapy [119].

Autologous stem cells transplantation is considered the most important \& most successful in preclinical \& clinical trials in PD [120]. They have many advantages in cell- based therapy as it doesn't need immunosuppression, easily harvest, cryopreservation \& expansion [121].

1. Mesenchymal Stem Cells:

Mesenchymal stem cells (MSCs) have been used in preclinical studies of PD either for production of neuroprotective factors or direct transplantation, which was found to reduce dopaminergic neuronal damage. Use of Mononuclear stem cells is found to be hazardous when it is compared to MSCs, it was found to accelerate damage \& cause deterioration of behavior [122, 123].

2. Adipose Derived Stem Cells:

Adipose derived stem cells (ADSCs) have been used in cell- based therapy, in-vitro culture of ADSCs showed 
increase in multiple cytokines \& neurotrophic factors that protect the rat models, when used, from the neurotoxic effect of 6-hydroxydopamine (6-OHDA) which is considered the main toxin cause degeneration of dopaminergic neurons [124, 125]. Transplantation of ADSCs in rhesus monkeys with hemi-parkinsonism shows improvement of symptoms \& behavior, thus it is considered a successful source of stem cells can be used in treatment of PD [126].

\section{Endometrial-derived SCs:}

Endometrial derived stem cells (EDSCS) recently have been used in preclinical trials of $\mathrm{PD}$, collection of endometrial was done by curettage from monkeys and transplanted in monkey models of PD, it showed survival, migration \& differentiation with improvement of dopamine production, this approach has many extra advantages than bone marrow derived MSCs which are the plenty of sources of endometrium with easier technical issues [127].

4. iPSCs:

Induced pluripotent stem cells (iPSCs) can be used to transform somatic cells into other progenitor cells, in the field of research of PD, human iPSCs are converted into neural progenitor cells and improve behavior when transplanted into rat model of PD \& survive for 6 months when transplanted into primate model [129, 130].

This approach solve many ethical problems regarding use of embryonic cells, also it abolish the use of immunosuppressant as there is no immune rejection. But the main challenges in iPSCs are tendency to neoplasia \& low productivity of neural cells form iPSCs, these two challenges are the main obstacle against use in clinical trials [131].

To overcome the disadvantages of iPSCs, direct transformation of somatic cells into neural cells without the step of iPSCs to from induced neural cells (iNs) [132]. Also direct transformation of fibroblast into induced dopaminergic cells (iDA cells) but it still need further researches to be approved in human trials [133].

Future challenges against using SCT in PD is the lack of animal model which perfectly exhibit the neuropathology of $\mathrm{PD}$, in rats treated with 1-methyl-4-phenyl- 1,2,3,6tetrahydropyridine (MTPT) - which is used for modeling PD- it show absence of Lewy bodies which is considered a key feature in pathophysiology of PD [128].

State Of The Art "Clinical trials" :

After these promising results on animals the next step was to enter the field of translation of these results in human trials, wishing for similar results. Various neurological diseases were candidates for stem cell therapy especially those with no available competent treatment such as amyotrophic lateral sclerosis, cerebral palsy, parkinsonism, multiple sclerosis and spinal cord injuries.

Challenges facing Translation of SC Therapy:

Stem cell therapy for NR faces a number of challenges. First is the procedure itself of injecting the cells into the central nervous systems of the patients with all its hazards and possible side effects. Another challenge is the efficacy of the therapy in inducing measurable improvement in neurological function. If this improvement is a fact, what is the exact biological mechanism underlying this process. The last and most important challenge is the type, source and exvivo manipulation of the stem cells.

Moreover, not all strategies developed in animal trials show the same efficacy in human trials. This may be due to the fact that animal models rarely reproduce identical disease models (75).

The next section will quickly review the current clinical trials involved in this field.

Amyotrophic Lateral Sclerosis:

Starting with amyotrophic lateral sclerosis, the first US food and drug administration approved clinical trial for stem cell treatment of ALS was on 2014[134].

1. Neural Stem Cells:

Human spinal cord derived neural stem cells were injected into cervical and lumbar regions. This study was to assess the safety and feasibility of the procedure. The procedure was well tolerated and disease progression didn't accelerate supporting future trial phases examining therapeutic doses and efficacy .

2. Hemopoeitic Stem Cells:

Another study on autologous transplantation of CD133(+) stem cells into the frontal motor cortex of ten patients revealed that it is a safe and well-tolerated procedure in ALS patients. The survival of treated patients was statistically higher than untreated control patients.[135]

3. Mesenchymal Stem Cells:

Continuing to confirm the feasibility and safety of the procedure, another study using a method of intraspinal cord implantation of autologous mesenchymal stem cells in a few well-monitored patients with ALS was performed. The results appear to demonstrate that the procedures of ex vivo expansion of autologous mesenchymal stem cells and of transplantation into the spinal cord of humans are safe and well tolerated by ALS patients.[136]

Cerebral Palsy:

1. Neural Progenitor Cells:

Trying to find adequate treatment for cerebral palsy, a trial to explore safety and efficacy of using neural progenitor cells (NPCs) to treat $\mathrm{CP}$ in children was performed in 2012[137].NPCs derived from aborted fetal tissue were injected into lateral ventricles. The motor development level in treatment group was significantly higher than that of control group.

2. Bone Marrow-Mononuclear Cells: $18 \mathrm{CP}$ patients were included in another trial to assess the safety of autologous bone marrow-derived total nucleated cell intrathecal and intravenous injection after stimulation with granulocyte colony-stimulating factor [138] The results showed that subarachnoid placement of autologous bone marrow-derived TNC in children with $\mathrm{CP}$ is a safe procedure with a possible increase in neurological function.

3. Bone Marrow-Mesenchymal Stem Cells:

52 patients with cerebral palsy received BM-MSC transplantation [139]. Gross motor function was assessed at baseline (before transplantation) and at 1 month, 6 months and 18 months post-transplantation. The treatment improved 
the development of children with $\mathrm{CP}$ with regard to motor function.

\subsection{Parkinson Disease}

Parkinsonism is one of the most challenging neurodegenerative diseases entered the field of the stem cell therapy.

1. Mesenchymal Stem Cells:

1. The first clinical trial to be applied in a no-option parkinsonism that aims to test the safety and to exploit the properties of autologous mesenchymal stem cells in reducing disease progression. [140]The study has been designed to test the safety of this "first-in-man" approach and to preliminarily explore its efficacy by excluding the placebo effect.

Another study to evaluate the feasibility, safety, and effectiveness of intra-arterial autologous implantation of adult stem cells for Parkinson disease was performed [141]. Patients showed significant improvement in disability, activities of daily living and depression and no complications were observed.

Seven patients were enrolled to participate in the prospective, uncontrolled, pilot study of single-dose, unilateral transplantation of autologous bone-marrow-derived mesenchymal stem cells. [142].A subjective improvement was found in symptoms like facial expression, gait, and freezing episodes. The results encourage future trials with more patients to demonstrate efficacy.

2. Adipose derived Stem Cells:

Two clinical trials are registered using ADSCs in PD, c clinical trial identifier NCT02184546 and NCT01453803, no data describing the results is available yet.

Traumatic Spinal Cord Injuries:

Stem cell therapy for SCI has passed through two phases: first phase used the concept of "central nervous system cellular grafts" and thus used the olfactory ensheathing cell grafts through surgical transplantation. The procedure was invasive, lengthy and the results were minimal. The second phase introduced the concept of non-neural stem cells such as:

1. Bone marrow derived Mesenchymal Stem Cells:

The most widely used stem cell due to their easy isolation, and multiple mechanisms of action in neuroregeneration.

2. Bone marrow derived Mononuclear cells:

Mononuclear cells encompass hemopoeitic stem cells and mesenchymal stem cells.

3. Neural progenitor cells:

Fetal neural progenitor cell implantation was also used in SCI

Table (2). Types of Stem Cells Used in Various Clinical Trials.

\begin{tabular}{|c|c|c|c|c|}
\hline Types of cells & Als & Alzheimer & Huntigton & Parkinson \\
\hline Mainly used cells & $\begin{array}{l}\text { MSCs } \\
\text { BM-MNCs } \\
\text { ADSCs }\end{array}$ & $A D S C s$ & $\begin{array}{l}\text { NSCs } \\
\text { ADSCs }\end{array}$ & MSCs \\
\hline Supporting cells & $\begin{array}{l}\text { - NPCs } \\
\text {-glial-restricted progenitor cells } \\
\text {-OESCs }\end{array}$ & $\begin{array}{l}\text {-GABAergic interneuron precursor cells } \\
\text {-Cord-blood derived MSCs-Bone marrow derived MSCs (BM- } \\
\text { MSCS) }\end{array}$ & BMCs-MSCs & ADSCs \\
\hline
\end{tabular}

\section{Conclusions}

After more than a decade of research in stem cell-induced neuroregeneration, we seem to have more questions than answers. Although research thus far documented the possiblity of induction of neuroregeneration through stem cell implantation, the underlying biological mechanisms remain obsecure. Ongoing research poses the questions of mechanism of action, optimum dose and optimum time for intervention. In addition, long-term safety is still a great concern.

Hopefully, future research will focus on these questions in order to pave the way for large -scale application of stem cell therapy for various neurological disorders.

\section{References}

[1] Herculano-Houzel S (2009): The Human Brain in Numbers: A linearly Scaled-up Primate Brain. Front Hum Neurosci, 3:31.PMCID: PMC2776484

[2] Neurological Disorders: public health challenges ISBN 924 1563362 .
[3] Mueller BK, Mueller R, Schoemaker H (2009): Stimulating neuroregeneration as a therapeutic drug approach for traumatic brain injury. $\mathrm{Br} \mathrm{J}$ Pharmacol 157(5):675-685. PMCID: PMC2721253.

[4] Eixarch H, Gutierrez-Franco A, Montalban X, Espejo C (2013): Semaphorins 3A and 7a : Potential immune and neuroregenerative targets in multiple sclerosis. Trends Mol Med 19(3):157-64.

[5] Zhu R, Cho KS, Chen DF, Yang L (2014): Ephrins A2 and A3 are negative regulators of the regenerative potential of Moller cells. Chin Med J 127(19):3438-42.

[6] Lyuksyutova AI, Lu CCm Milanesio N, KIing LA, Guo N, Wang Y, Nathans J, Tessier-Layigne M , Zou Y (2003): Anterior-posterior guidance of commissural axons by Wntfrizzled signaling. Science 302(5652):1984-8.

[7] Liu J, Wu X, Mitchell B, Kintner C, Ding S, Schultz PG (2005): A small-molecule agonist of the Wnt signaling pathway. Angew Chem Int Ed Engl 44(13):1987-90.

[8] Arvanian VL, Schnell L, Lou L, Golshani R, Hunanyan A, Ghosh A, Pearse DD, Robinson JK, M. Schwab ES, Fawcett JW, and Mendell LM (2009): Chronic spinal hemisection in rats induces a progressive decline in transmission in uninjured fibers to motoneurons. Exp.Neurol. 216 (2):471-480. 
[9] Zhao RR, Andrews MR, Wang D, Warren P, Gullo M, Schnell L, Schwab ME, Fawcett JW (2013) Combination treatment with anti-Nogo-A and chondroitinase $\mathrm{ABC}$ is more effective than single treatments at enhancing functional recovery after spinal cord injury. Eur J Neurosci 38:2946-2961.

[10] Hunanyan AH, Garcia-Alias G, Alessi V, Levine JM, Fawcett JW, Mendell LM, and Arvanian LV (2010): Role of chondroitin sulfate proteoglycans in axonal conduction in Mammalian spinal cord. J.Neurosci. 30 (23):7761-7769.

[11] Weissmiller AM and Wu C (2012): Current advances in using neurotrophic factors to treat neurodegenerative disorders. Translational Neurodegeneration 1:14.

[12] Tabakow P, Jarmundowjca W, CzapigaB, Fortuna W, Miedzybrodzki R, Czyz M, Huber J, Szarek D, Okurowski S, Szewczyk P, Gorski A, Raisman G (2013: Transplantation of autologous olfactory ensheathing cells in complete human spinal cord injury. Cell Transplant Apr 2 [Epub ahead of print]

[13] Barker RA, Barrett J, Bjorklund A (2013): Fetal dopaminergic transplantation trials ant the future of neural grafting in Parkinson's disease. Lancet Neurol 12(1):84-91.

[14] Huebner EA an Strittmatter SM (2009): Axon Regeneration in the Peripheral and Central Nervous Systems. Results Probl Cell Differ 48:339-351.

[15] Burnett MG an Zager EL (2004): Pathophysiology of peripheral nerve injury: a brief review. Neurosurg Focus 16(5): Article 1.

[16] Cafferty WB, Yang S-H, Duffy PJ, Li S, Strittmatter SM. (2007): Functional axonal regeneration through astrocytic scar genetically modified to digest chondroitin sulfate proteoglycans. JNeurosci.27:2176-2185.

[17] Lallemend $\mathrm{F}^{1}$, Sterzenbach U, Hadjab-Lallemend S, Aquino JB, Castelo-Branco G, Sinha I, Villaescusa JC, Levanon D, Wang Y, Franck MC, Kharchenko O,Adameyko I, Linnarsson S, Groner Y, Turner E, Ernfors P (2012): Postional differences of axon growth rates between sensory neurons encoded by Runx3. EMBO J 31(18):3718-29.

[18] Coletti D, Teodori L, Zhenlin L, Beranudin JF and Adamo S (2013): Restoration versus reconstruction: cellular mechanisms of skin, nerve an muscle regeneration compared. Regenerative Medicine Research 1:4.

[19] Ferguson TA and Son Y (2011): Extrinsic and intrinsic determinants of nerve regeneration. J Tissue Eng 2(1):2041731411418392.

[20] Tohill M, Mantovani C, Wiberg M and Terenghi G (2004): Rat bone marrow mesenchymal stem cells express glial markers and stimulate nerve regeneration. Neuroscience Letters 362(3):200-203.

[21] Huang WH1, Chang MC, Tsai KS, Hung MC, Chen HL, Hung SC (2013): Mesenchymal stem cells promote growth and angiogenesis of tumors in mice. Oncogene 32(37):4343-54.

[22] Glavaski-Joksimovic A and Bohn MC (2013): Mesenchymal stem cells and neuroregeneration in Parkinson's disease. Exp Neurol 247:25-38.

[23] Baraniak PR and McDevitt T (2010): Stem cell paracrine actions and tissue regeneration. Regen Med 5(1):121-143.

[24] Kassis I ${ }^{1}$, Grigoriadis N, Gowda-Kurkalli B, Mizrachi-Kol R,
Ben-Hur T, Slavin S, Abramsky O, Karussis D.(2008): Neuroprotection and immunomodulation with mesenchymal stem cells in chronic experimental autoimmune encephalomyelitis. Arch Neurol. 65(6):753-61.

[25] Tomaskovic-Crook E and Crook JM (2011): Human embryonic stem cell therapies for neurodegenerative diseases. CNS Neurol Disord Drug Targets 10(4):440-8.

[26] Roszek K and Czarneka J (2014): Perspectives of mesenchymal stem cell-based neuroregeneration. J Stem Cell Res, Rev \& Rep; 1(3):1012.

[27] Anand A, Thakur K, Gupta PK. (2013): ALS and oxidative stress: the neurovascular scenario. Oxid Med Cell Longev 2013:635831.

[28] Xinyi Li, Eliezer Masliah, Natàlia Reixach, and Joel N. Buxbaum (2011): Neuronal Production of Transthyretin in Human and Murine Alzheimer's Disease: is it Protective?J Neurosci. 31(35): 12483-12490.

[29] Caltagirone C, Ferrannini L, Marchionni N, Nappi G, Scapagnini G, Trabucchi M.(2012): The potential protective effect of tramiprosate (homotaurine) against Alzheimer's disease: a review. Aging Clin Exp Res 24(6):580-7.

[30] Nimmrich V, Eckert A.(2013): Calcium channel blockers and dementia. Br J Pharmacol ;169(6):1203-10.

[31] Schaeffer EL, da Silva ER, Novaes B de A, Skaf HD, Gattaz WF. (2010): Differential roles of phospholipases A2 in neuronal death and neurogenesis: implications for Alzheimer disease. Prog Neuropsychopharmacol Biol Psychiatry;34(8):1381-9.

[32] Gentile MT, Reccia MG, Sorrentino PP, Vitale E, Sorrentino G, Puca AA, Colucci-D'Amato L. (2012); Role of cytosolic calcium-dependent phospholipase A2 in Alzheimer's disease pathogenesis. Mol Neurobiol; 45(3):596-604.

[33] Singh MS, MacLaren RE. (2011): Stem cells as a therapeutic tool for the blind: biology and future prospects. Proc Biol Sci ;278(1721):3009-16.

[34] Zhou Y, Sun M, Li H, Yan M and Xie T (2012): Differentiation of rhesus adipose stem cells into dopaminergic neurons. Neual Regen Res 7(34):2645-2652.

[35] Jacob A, Alexander JJ.(2014): Complement and blood-brain barrier integrity. Mol Immunol ;61(2):149-52.

[36] Towne C, Setola V, Schneider BL, Aebischer P.(2011): "Neuroprotection by Gene Therapy Targeting Mutant SOD1 in Individual Pools of Motor Neurons Does not Translate Into Therapeutic Benefit in fALS Mice. Mol. Ther.

[37] Park H, Cho J, Park C, Jung S, Park C, Lee S, Oh S, Park Y, and Chang M (2012): Directed Induction of Functional Motor Neuron-like Cells from Genetically Engineered Human Mesenchymal Stem Cells. PLoS One 7(4):e35244.

[38] Li Y, Balasubramanian U, Cohen D, Zhang P-W, Mosmiller E, Sattler R, et al.(2015): "A comprehensive library of familial human amyotrophic lateral sclerosis induced pluripotent stem cells". PloS one. Jan ;10(3):e0118266.

[39] Di Giorgio FP, Carrasco MA, Siao MC, Maniatis T, Eggan K.(2007): "Non-cell autonomous effect of glia on motor neurons in an embryonic stem cell-based ALS model" . Nat. Neurosci.; 10(5):608-614. 
[40] Wyatt TJ, Rossi SL, Siegenthaler MM, Frame J, Robles R, Nistor G, Keirstead HS. (2011): "Human motor neuron progenitor transplantation leads to endogenous neuronal sparing in 3 models of motor neuron loss". Stem Cells Int.; 2011:207230

[41] Suzuki M, McHugh J, Tork C, Shelley B, Hayes A, Bellantuono I, Aebischer P, Svendsen CN. (2008): "Direct muscle delivery of GDNF with human mesenchymal stem cells improves motor neuron survival and function in a rat model of familial ALS". Mol. Ther. 2008; 16(12):2002-2010.

[42] King A, Liu L (2013): Stem cell therapy for Alzheimer's disease: hype or hope?Bioscience Horizons 6 :hzt011

[43] Lee JC, Seong J, Kim SH, Lee SJ, Cho YJ, An J, et al(2012): "Replacement of microglial cells using Clodronate liposome and bone marrow transplantation in the central nervous system of SOD1(G93A) transgenic mice as an in vivo model of amyotrophic lateral sclerosis". Biochemical and biophysical research communications. Feb10; 418(2) :359-65.

[44] Gamez J, Carmona F, Raguer N, Ferrer-Sancho J, MartinHenao GA, Marti-Beltran S et al (2010): . "Cellular transplants in amyotrophic lateral sclerosis patients: an observational study". Cytotherapy; 12(5):669-677.

[45] Allers C, Jones JA, Lasala GP, Minguell JJ.(2014): "Mesenchymal stem cell therapy for the treatment of amyotrophic lateral sclerosis: signals for hope?" Regenerative medicine ;9(5):637-47.

[46] Pastor D, Viso-Leon MC, Jones J, Jaramillo-Merchan J, Toledo-Aral JJ, Moraleda JM, et al(2011): "Comparative Effects between Bone Marrow and Mesenchymal Stem Cell Transplantation in GDNF Expression and Motor Function Recovery in a Motorneuron Degenerative Mouse Model" Stem Cell Rev. 8(2):445-58.

[47] Kaspar BK.(2008): "Mesenchymal stem cells as trojan horses for GDNF delivery in ALS”. Mol. Ther. ; 16(12):1905-1906.

[48] Kim C, Lee HC, Sung J-J (2014): . “Amyotrophic lateral sclerosis - cell based therapy and novel therapeutic development". Experimental neurobiology; 23(3):207-14.

[49] Kim KS, Lee HJ, An J, Kim YB, Ra JC, Lim I, et al (2014): "Transplantation of human adipose tissue-derived stem cells delays clinical onset and prolongs life span in ALS mouse model". Cell transplantation; 23(12):1585-97.

[50] Marconi S, Bonaconsa M, Scambi I, Squintani GM, Rui W, Turano E, et al.(2013): "Systemic treatment with adiposederived mesenchymal stem cells ameliorates clinical and pathological features in the amyotrophic lateral sclerosis murine model". Neuroscience; 248:333-43.

[51] Lopez-Gonzalez R, Kunckles P, Velasco I. (2009): “Transient recovery in a rat model of familial amyotrophic lateral sclerosis after transplantation of motor neurons derived from mouse embryonic stem cells". Cell Transplant ; 18:1171-1181.

[52] Xu L, Ryugo DK, Pongstaporn T et al. (2009): "Human neural stem cell grafts in the spinal cord of SOD1 transgenic rats: Differentiation and structural integration into the segmental motor circuitry". J Comp Neurol; 514: 297-309.

[53] Lunn JS, Sakowski SA, Feldman EL.(2014): “Concise review: Stem cell therapies for amyotrophic lateral sclerosis: recent advances and prospects for the future. Stem cells"; 32(5):1099-109.
[54] Lepore AC, Rauck B, Dejea C et al. (2008): "Focal transplantation-based astrocyte replacement is neuroprotective in a model of motor neuron disease". Nat Neurosci; 11:1294 1301.

[55] Li Y, Bao J, Khatibi NH et al.(2011): “Olfactory ensheathing cell transplantation into spinal cord prolongs the survival of mutant SOD1(G93A) ALS rats through neuroprotection and remyelination" Anat Rec (Hoboken); 294:847-857.

[56] Rowland LP, Shneider NA. (2001): "Amyotrophic lateral sclerosis”. N. Engl. J. Med.; 344(22):1688- 1700.

[57] Kirkinezos IG, Hernandez D, Bradley WG, Moraes CT. " Regular exercise is beneficial to a mouse model of amyotrophic lateral sclerosis". Ann. Neurol. 2003; 53(6):804807.

[58] Kaspar BK, Frost LM, Christian L, Umapathi P, Gage FH. "Synergy of insulin-like growth factor-1 and exercise in amyotrophic lateral sclerosis". Ann. Neurol. 2005; 57(5):649655.

[59] Liebetanz D, Hagemann K, von Lewinski F, Kahler E, Paulus W. "Extensive exercise is not harmful in amyotrophic lateral sclerosis". Eur. J. Neurosci. 2004; 20(11):3115-3120.

[60] Chung C, Fujita N, Kawahara N, Yui S, Nam E and Nishimura R (2013): A Comparison of Neurosphere Differentiation Potential of Canine Bone Marrow-Derived Mesenchymal Stem Cells and Adipose-Derived Mesenchymal Stem Cells. Journal of Veterinary Medical Science ; 75(7). DOI: 10.1292/jvms. $12-0470$

[61] Suzuki M, Svendsen CN. "Combining growth factor and stem cell therapy for amyotrophic lateral sclerosis". Trends in neurosciences. 2008 Apr ; 31(4):192-8.

[62] Schnabel, J., 2008. Neuroscience: standard model. Nature 454 (7205), 682-685.

[63] Scott, S., Kranz, J.E., Cole, J., Lincecum, J.M., Thompson, K., Kelly, N. et al. " Design, power, and interpretation of studies in the standard murine model of ALS". Amyotroph. Lateral Scler. 9 (1), 4-15.

[64] Thomsen GM, Gowing G, Svendsen S, Svendsen CN. "The past, present and future of stem cell clinical trials for ALS". Experimental neurology. 2014 Dec; 262 Pt. B: 127-37.

[65] Tong LM, Fong H, Huang Y. "Stem cell therapy for Alzheimer's disease and related disorders: current status and future perspectives" Experimental \& molecular medicine 47:e151.

[66] Lee HJ, Kim KS, Kim EJ, Choi HB, Lee KH, Park IH et al. "Brain transplantation of immortalized human neural stem cells promotes functional recovery in mouse intracerebral hemorrhage stroke model". Stem Cells 2007; 25:1204-1212.

[67] Yamasaki TR, Blurton-Jones M, Morrissette DA, Kitazawa M, Oddo S, LaFerla FM. "Neural stem cells improve memory in an inducible mouse model of neuronal loss". JNeurosci2007; 27: 11925-11933.

[68] Xuan AG, Luo M, Ji WD, Long DH. "Effects of engrafted neural stem cells in Alzheimer's disease rats". Neurosci Lett 2009; 450:167-171.

[69] Xuan AG, Long DH, Gu HG, Yang DD, Hong LP, Leng SL. " BDNF improves the effects of neural stem cells on the rat model of Alzheimer's disease with unilateral lesion of fimbriafornix". Neurosci Lett 2008; 440: 331-335. 
[70] Blurton-Jones M, Kitazawa M, Martinez-Coria H, Castello NA, Muller FJ, Loring JF et al. "Neural stem cells improve cognition via BDNF in a transgenic model of Alzheimer disease". Proc Natl Acad Sci USA 2009; 106: 13594-13599

[71] Hampton DW, Webber DJ, Bilican B, et al. "Cell-mediated neuroprotection in a mouse model of human tauopathy". J Neurosci. 2010; 30:9973-9983.

[72] Zhang W, Wang P, Gu G, Li M, Gao X. "Effects of neural stem cells transplanted into an animal model of Alzheimer disease on A $\beta$ plaques". Zhonghua yi xue za zhi. 2013 Dec 3; 93(45):3636-9.

[73] Kim SU, Lee HJ, Kim YB. "Neural stem cell-based treatment for neurodegenerative diseases. Neuropathology" 2013; $33: 491-504$

[74] Ma, T.; Gong, K.; Ao, Q.; Yan, Y.; Song, B.; Huang, H.; Zhang, X.; Gong, Y. "Intracerebral transplantation of adipose-derived mesenchymal stem cells alternatively activates microglia and ameliorates neuropathological deficits in Alzheimer's disease mice”. Cell Transplant. 22(S1):113-126; 2013.

[75] Kim, H. S.; Suh, Y. H. "The preventive and therapeutic effects of intravenous human adipose-derived stem cells in Alzheimer's disease mice”. PLoS One 7(9):e45757; 2012.

[76] Chang K-A, Kim HJ, Joo Y, Ha S, Suh Y-H. "The therapeutic effects of human adipose-derived stem cells in Alzheimer's disease mouse models." Neuro-degenerative diseases. 2014 Jan;13 (2-3):99-102.

[77] Katsuda T, Oki K, Ochiya T. "Potential Application of Extracellular Vesicles of Human Adipose Tissue-Derived Mesenchymal Stem Cells in Alzheimer's Disease Therapeutics". Methods in molecular biology. 2014 Aug 2

[78] Tricoire L, Pelkey KA, Erkkila BE, Jeffries BW, Yuan X, McBain CJ. "A blueprint for the spatiotemporal origins of mouse hippocampal interneuron diversity". J Neurosci 2011; 31: $10948-109707$

[79] Tong LM, Djukic B, Arnold C, Gillespie AK, Yoon SY, Wang $\mathrm{MM}$ et al. "Inhibitory interneuron progenitor transplantation restores normal learning and memory in apoE4 knock-in mice without or with $A \beta$ accumulation". JNeurosci2014; 34:95069515 .

[80] Daadi MM, Lee SH, Arac A, Grueter BA, Bhatnagar R, Maag $\mathrm{AL}$ et al. "Functional engraftment of the medial ganglionic eminence cells in experimental stroke model". Cell Transplant $2009 ; 18: 815-826$.

[81] Morgan RJ, Santhakumar V, Soltesz I. Modeling the dentate gyrus. Prog Brain Res 2007; 163:639-658.

[82] Liu Y, Weick JP, Liu H, Krencik R, Zhang X, Ma L et al. "Medial ganglionic eminence-like cells derived from human embryonic stem cells correct learning and memory deficits". Nat Biotechnol 2013; 31:1-10.

[83] Akiyama H, Barger S, Barnum S, et al. "Inflammation and Alzheimer's disease”. Neurobiol Aging. 2000; 21:383-421.

[84] Ylostalo JH, Bartosh TJ, Coble K, et al. "Human Mesenchymal Stem/Stromal Cells (hMSCs) Cultured as Spheroids are Self-activated to Produce Prostaglandin E2 (PGE2) that Directs Stimulated Macrophages into an Antiinflammatory Phenotype". Stem Cells. 2012
[85] Kim JY, Kim DH, Kim JH, et al. "Soluble intracellular adhesion molecule-1 secreted by human umbilical cord bloodderived mesenchymal stem cell reduces amyloid-beta plaques”. Cell Death Differ. 2011; 19:680-691.

[86] Nikolic WV, Hou H, Town T, et al. "Peripherally administered human umbilical cord blood cells reduce parenchymal and vascular beta-amyloid deposits in Alzheimer mice". Stem Cells Dev. 2008; 17:423-439.

[87] Salem AM, Ahmed HH, Atta HM, Ghazy MA, Aglan HA. "Potential of bone marrow mesenchymal stem cells in management of Alzheimer's disease in female rats". Cell biology international. 2014 Dec ;38(12):1367-83.

[88] Chen WW, Blurton-Jones M. Concise review: Can stem cells be used to treat or model Alzheimer's disease? Stem cells . 2012 Dec ;30(12):2612-8.

[89] Mollison KW, Fey TA, Krause RA, et al. "Nephrotoxicity studies of the immunosuppressants tacrolimus (FK506) and ascomycin in rat models". Toxicology. 1998; 125:169-181.

[90] Maucksch C, Vazey EM, Gordon RJ, Connor B. Stem cellbased therapy for Huntington's disease. Journal of cellular biochemistry.2013 Apr; 114(4):754-63.

[91] Beal MF, Ferrante RJ, Swartz KJ, Kowall NW. "Chronic quinolinic acid lesions in rats closely resemble Huntington's disease". J Neurosci 1991; 11:1649- 1659.

[92] Blum D, Gall D, Cuvelier L, Schiffmann SN.“Topological analysis of striatal lesions induced by 3-nitropropionic acid in the Lewis rat" Neuroreport 2001; 12:1769-1772.

[93] Beal MF, Brouillet E, Jenkins BG, Ferrante RJ, Kowall NW. "Neurochemical and histologic characterization of striatal excitotoxic lesions produced by the mitochondrial toxin 3nitropropionic acid" J Neurosci 1993; 13:4181-4192

[94] Ryu JK, Kim J, Cho SJ, Hatori K, Nagai A, Choi HB, Lee MCTf, McLarnon JG, Kim SU. "Proactive transplantation of human neural stem cells prevents degeneration of striatal neurons in a rat model of Huntington disease". Neurobiol Dis 2004; 16:68-77

[95] McBride JL, Behrstock SP, Chen EY, Jakel RJ, Siegel I, Svendsen CN, Kordower JH. "Human neural stem cell transplants improve motor function in a rat model of Huntington's disease". J Comp Neurol 2004; 475:211 219

[96] Lee ST, Park JE, Lee K, Kang L, Chu K, Kim SU, Kim M, Roh JK. "Noninvasive method of immortalized neural stemlike cell transplantation in an experimental model of Huntington's disease". J Neurosci Methods 2006; 152: 250254.

[97] Kim M, Lee S-T, Chu K, Kim SU. "Stem cell-based cell therapy for Huntington disease: a review. Neuropathology: official journal of the Japanese Society of Neuropathology" 2008; 28(1):1-9.

[98] Im, W.; Lee, S. T.; Park, J. E.; Oh, H. J.; Shim, J.; Lim, J.; 31. Chu, K.; Kim, M. "Transplantation of patient-derived adipose stem cells in YAC128 Huntington's disease transgenic mice". PLoS Curr. 2:RRN1183; 2010.

[99] Vazey EM, Dottori M, Jamshidi P, Tomas D, Pera MF, Horne M, Connor B. "Comparison of transplant efficiency between spontaneously derived and noggin-primed human embryonic stem cell neural precursors in the quinolinic acid rat model of Huntington's disease". Cell Transplant 2010; 19:1055- 1062 
[100] Maucksch, C.; Vazey, E. M.; Gordon, R. J.; Connor, B. 49. Stem cell-based therapy for Huntington's disease. J. Cell. Biochem. 114(4):754-763; 2013.

[101] Liu T, Im W, Lee S-T, Ban J-J, Chai YJ, Lee M, et al. "Modulation of mitochondrial function by stem cell-derived cellular components" Biochemical and biophysical research communications. 2014; 448(4):403-8.

[102] Jiang Y, Lv H, Huang S, Tan H, Zhang Y, Li H. "Bone marrow mesenchymal stem cells can improve the motor function of a Huntington's disease rat model". Neurological research. 2011; 33(3):331-7.

[103] Serrano Sánchez T, Alberti Amador E, Lorigados Pedre L, Blanco Lezcano L, Diaz Armesto I, Bergado JA. "BDNF in quinolinic acid lesioned rats after bone marrow cells transplant." Neuroscience letters. 2014; 559:147-51.

[104] Snyder BR, Chiu AM, Prockop DJ, Chan AW. "Human multipotent stromal cells (MSCs) increase neurogenesis and decrease atrophy of the striatum in a transgenic mouse model for Huntington's disease" PLoS ONE 2010; 5:e9347

[105] Lin YT, Chern Y, Shen CK, Wen HL, Chang YC, Li H, Cheng TH, Hsieh-Li HM. "Human mesenchymal stem cells prolong survival and ameliorate motor deficit through trophic support in Huntington's disease mouse models" PLoS ONE 2011 6:e22924.

[106] Rossignol J, Fink K, Davis K, Clerc S, Crane A, Matchynski J, et al. "Transplants of adult mesenchymal and neural stem cells provide neuroprotection and behavioral sparing in a transgenic rat model of Huntington's disease". Stem cells. 2014; 32(2):500-9.

[107] Sadan O, Shemesh N, Cohen Y, Melamed E, Offen D. “Adult neurotrophic factor-secreting stem cells: a potential novel therapy for neurodegenerative diseases." The Israel Medical Association journal : IMAJ. 2009; 11(4):201-4.

[108] Petit GH, Olsson TT, Brundin P. "The future of cell therapies and brain repair: Parkinson's disease leads the way". Neuropathology and applied neurobiology. 2014; 40(1):60-70.

[109] de Munter JP, Wolters EC. 'Autologous stem cells in neurology: is there a future?" J Neural Transm 2013; 120:6573.

[110] de Munter JPJM, Melamed E, Wolters EC. "Stem cell grafting in parkinsonism--why, how and when. Parkinsonism \& related disorders” 2014; 20 Suppl 1:S150-3.

[111] Capitelli CS, Lopes CS, Alves AC, Barbiero J, Oliveira LF, da Silva VJD, et al. "Opposite effects of bone marrow-derived cells transplantation in MPTP-rat model of Parkinson's disease: a comparison study of mononuclear and mesenchymal stem cells" International journal of medical sciences. 2014; 11(10):1049-64.

[112] Glavaski-Joksimovic A, Bohn MC. "Mesenchymal stem cells and neuroregeneration in Parkinson's disease" Experimental neurology. 2013; 247:25-38.

[113] Gombash SE, Lipton JW, Collier TJ, Madhavan L, SteeceCollier K, Cole-Strauss A, et al. "Striatal pleiotrophin overexpression provides functional and morphological neuroprotection in the 6-hydroxydopamine model". Molecular therapy : the journal of the American Society of Gene Therapy. 2012; 20(3):544-54.
[114] Gu, H.; Wang, J.; Du, N.; Tan, J.; Johnstone, B.; Du, Y. "Adipose stromal cells-conditioned medium blocks 6hydroxydopamine induced neurotoxicity and reactive oxygen species". Neurosci. Lett. 544:15-19; 2013.

[115] Zhou, Y.; Sun, M.; Li, H.; Yan, M.; He, Z.; Wang, W.; Lu, 87. S. "Recovery of behavioral symptoms in hemi-parkinsonian rhesus monkeys through combined gene and stem cell therapy" Cytotherapy 15(4):467-480; 2013.

[116] Wolff EF, Mutlu L, Massasa EE, Elsworth JD, Eugene Redmond D, Taylor HS. "Endometrial stem cell transplantation in MPTP- exposed primates: an alternative cell source for treatment of Parkinson's disease" Journal of cellular and molecular medicine. 2015; 19(1):249-56.

[117] Speciale SG. "MPTP Insights into parkinsonian neurodegeneration. Neurotoxicol Teratol" 2002; 24:607-620.

[118] Wernig M, Zhao J-P, Pruszak J, Hedlund E, Fu D, Soldner F, Broccoli Vet al. "Neurons derived from reprogrammed fibroblasts functionally integrate into the fetal brain and improve symptoms of rats with Parkinson's disease" Proc Natl Acad Sci USA2008; 105: 5856-61.

[119] Kikuchi T, Morizane A, Doi D, Onoe H, Hayashi T, Kawasaki T, Saiki H, Miyamoto S, Takahashi J. "Survival of human induced pluripotent stem cell-derived midbrain dopaminergic neurons in the brain of a primate model of Parkinson's disease". J Parkinsons Dis 2011; 1: 395-412.

[120] Okano H, Yamanaka S. "iPS cell technologies: significance and applications to CNS regeneration and disease" Molecular brain. $2014 ; 7: 22$

[121] Vierbuchen T, Ostermeier A, Pang ZP, Kokubu Y, Südhof TC, Wernig M. "Direct conversion of fibroblasts to functional neurons by defined factors" Nature 2010; 463: 1035-41.

[122] Pfisterer U, Kirkeby A, Torper O, Wood J, Nelander J, Dufour A et al. "Direct conversion of human fibroblasts to dopaminergic neurons" Proc Natl Acad SciUSA2011; 108: 10343-8

[123] .Riley, J., Glass, J., Feldman, E. L., Polak, M., Bordeau, J., Federici, T., ... Boulis, N. M. (2014). Intraspinal stem cell transplantation in amyotrophic lateral sclerosis: A phase I trial, cervical microinjection, and final surgical safety outcomes. Neurosurgery, 74(1), 77-87.

[124] Martinez, H. R., Gonzalez-Garza, M. T., Moreno-Cuevas, J. E., Caro, E., Gutierrez-Jimenez, E., \& Segura, J. J. (2009). Stemcell transplantation into the frontal motor cortex in amyotrophic lateral sclerosis patients. Cytotherapy (Vol. 11).

[125] Mazzini, L., Fagioli, F., Boccaletti, R., Mareschi, K., Oliveri, G., Olivieri, C., ... Madon, E. (2003). Stem cell therapy in amyotrophic lateral sclerosis: a methodological approach in humans. Amyotrophic lateral sclerosis and other motor neuron disorders : official publication of the World Federation of Neurology, Research Group on Motor Neuron Diseases (Vol. 4).

[126] Luan, Z., Liu, W., Qu, S., Du, K., He, S., Wang, Z., ... Gong, X. (2012). Effects of neural progenitor cell transplantation in children with severe cerebral palsy. Cell Transplantation, 21(SUPPL. 1).

[127] Mancías-Guerra, C., Marroquín-Escamilla, A. R., GonzálezLlano, O., Villarreal-Martínez, L., Jaime-Pérez, J. C., GarcíaRodríguez, F., ... Gómez-Almaguer, D. (2014). Safety and tolerability of intrathecal delivery of autologous bone marrow nucleated cells in children with cerebral palsy: An open-label phase I trial. Cytotherapy, 16(6), 810-820. 
[128] Wang, X., Cheng, H., Hua, R., Yang, J., Dai, G., Zhang, Z., ... An, Y. (2013). Effects of bone marrow mesenchymal stromal cells on gross motor function measure scores of children with cerebral palsy: A preliminary clinical study. Cytotherapy, 15(12), 1549-1562.

[129] Giordano, R., Canesi, M., Isalberti, M., Isaias, I. U., Montemurro, T., Viganò, M., ... Pezzoli, G. (2014). Autologous mesenchymal stem cell therapy for progressive supranuclear palsy: translation into a phase I controlled, randomized clinical study. Journal of Translational Medicine, 12,14 .

[130] Brazzini, A., Cantella, R., De la Cruz, A., Yupanqui, J., León, C., Jorquiera, T., ... Saenz, L. N. (2010). Intraarterial autologous implantation of adult stem cells for patients with Parkinson disease. Journal of vascular and interventional radiology : JVIR (Vol. 21).

[131] Venkataramana, N. K., Kumar, S. K. V, Balaraju, S., Radhakrishnan, R. C., Bansal, A., Dixit, A., ... Totey, S. M.
(2010). Open-labeled study of unilateral autologous bonemarrow-derived mesenchymal stem cell transplantation in Parkinson's disease. Translational Research, 155(2), 62-70.

[132] Dai, G., Liu, X., Zhang, Z., Yang, Z., Dai, Y., \& Xu, R. (2013) Transplantation of autologous bone marrow mesenchymal stem cells in the treatment of complete and chronic cervical spinal cord injury. Brain Research, 1533, 73-79.

[133] Frolov, A. A., \& Bryukhovetskiy, A. S. (2012). Effects of hematopoietic autologous stem cell transplantation to the chronically injured human spinal cord evaluated by motor and somatosensory evoked potentials methods. Cell Transplantation, 21(SUPPL. 1).

[134] Cristante, A. F., Barros-Filho, T. E. P., Tatsui, N., Mendrone, A., Caldas, J. G., Camargo, A., ... Marcon, R. M. (2009). Stem cells in the treatment of chronic spinal cord injury: evaluation of somatosensitive evoked potentials in 39 patients. Spinal cord : the official journal of the International Medical Society of Paraplegia (Vol. 47). 